\title{
Analyzing Cultural Issues in High School English Textbooks in Japan
}

\author{
Kouki Ookawa \\ high school teacher, Misaki High School \\ Apartment No. 206 Sugawa 5, Honai-cho \\ Yawatahama City, Ehime Prefecture, Japan \\ E-mail: kookawa321@yahoo.co.jp
}

Received: March 4, 2016 Accepted: April 8, 2016 Published: April 13, 2016

doi:10.5296/ijele.v4i2.9308 URL: http://dx.doi.org/10.5296/ijele.v4i2.9308

\begin{abstract}
It cannot be denied that intercultural understanding is crucial in the process of learning English at elementary school, junior high school, high school, and so on. This paper analyzes the high school English textbooks approved by the Ministry of Education, Culture, Sports, Science and Technology (henceforth, MEXT) in Japan from the perspective of intercultural understanding. It elucidates the types of the articles, the countries treated in the articles, and the purposes of the materials for cultural understanding. Then it discusses the characteristics of the cultural materials presented in the high school English textbooks. The result of the research shows the materials contain various kinds of categories, many materials concerning English-speaking countries. However, an important fact is that there is still too much focus on Japan and America. Finally, the paper suggests the future direction of the materials in the textbooks in order to facilitate the better intercultural understanding in the global world.
\end{abstract}

Keywords: intercultural understanding, cultural materials, English textbooks 


\section{Introduction}

In Japan high school educational guidance is revised for the first time in about ten years, and present textbooks based on the new government guidelines for teaching have been used since 2013. The overall objective in English is described as follows by the government guidelines. The Courses of Study (Monbuskagakusho, 2010) says that the objective is to develop students' communication abilities such as accurately understanding and appropriately conveying information, ideas, etc., deepening their understanding of language and culture, fostering a positive attitude toward communication through foreign languages. It is worth considering the elements and topics of culture presented in the textbooks because one of the objectives is to deepen students' understanding of language and culture.

In the present study, the authorized Communication English I textbooks have been analyzed from the perspective of intercultural understanding. In particular, the study focused on main passages of each lesson and examined the information presented in the passage for cultural understanding. The present study was conducted in order to elucidate the cultural information for students' cultural understanding. Based on the results of the analysis of the textbooks, this research discusses the better cultural materials so that Japanese students can develop their skills of English in the global age.

\section{Literature Review}

\subsection{Previous Studies of English textbooks}

Numerous researches have been performed concerning the subject matters shown in the English textbooks under the former government guidelines in Japan. As Hino (1988) indicates the tendency of the Japanese English textbooks, the Japanese government has employed many American topics for a long period except the second world war because Japan followed the American value. In recent years, Schneer (2007) also discusses the strong effect of the political power on English textbooks. In countries outside Japan, numerous quantitative and qualitative analyses of English textbooks have been performed (e.g. Alptekin, 1993; Martin Cortazzi and Lixian Jin, 1999; Chakravati, 2008; Recorari et al., 2012; Weninger and Kiss, 2013 ). Aleptekin (1993) gave an example of the topic of the White House frequently treated in the American textbooks. Chakravai (2008) analyzed the English textbooks in contemporary West-Bengal, India and suggested the new demand for English language proficiency in a globalizing India. Recorari et al. (2012) researched attitudes of over 1,000 students at three Swedish universities toward English language textbooks in tertiary education and discussed implications for the English as a foreign language as a second language classroom. In this way, the importance of the English textbooks has been discussed, although situations in which students learn English differ from country to country.

Next, in the field of the cultural materials shown in high school English textbooks in Japan, some results were reported. First, many articles about everyday life were treated in the English textbooks of high school (Muroi, 1999; Muroi 2004; Yamanaka, 2004). According to Yamanaka (2004), as a result of investigating ten English textbooks used at high school and classifying the contents into the cultural categories, it was said that about half of the lessons 
included the contents of everyday life. Second, many materials concerning English-speaking countries, such as Britain and the United States, were treated in the high school English textbooks (Muroi, 1999; Muroi 2004; Yamanaka, 2004). For instance, Muroi (2004) researched top ten high school English textbooks of an adoption rate and stated that $24 \%$ of the textbooks treated the countries of Inner Circle suggested by Kachru (1989). Yamanaka (2006) analyzed ten textbooks of English I used at high school, and stated many of the subject articles and words concerning English-speaking nations, such as the United States, Britain, and Australia were found in those textbooks. Third, There were many subject matters about Japan (Muroi, 1999; Muroi, 2004; Yamanaka, 2006). Muroi (2004) researched top ten in sale of high school English textbooks of English I and English II and reported that the lessons treating Japan occupied $22 \%$ of the whole in English I and formed 17\% of the whole in English II. Lastly, in terms of the topics, the global themes, such as environment and war, exists at some extent (Muroi, 1999; Shikano, 2001). Shikano (2001) chose 18 textbooks of English I and English II used at high school and stated that the lessons treating environment, human rights, and three global problems of war occupied about $20 \%$ of all the lessons.

As can be seen in the results, previous contents of the high school textbooks were elucidated from cultural perspectives. However, present textbooks do not seem to have been analyzed from the perspective of cultural understanding in details

\subsection{Teaching of Culture in EFL classes}

Byran (1990) stated that there are four components in teaching culture; language learning, language awareness, cultural awareness, and cultural experience. He insisted that balance and cohesion of the four components were crucial because they were supportive elements for each other. However, there is a clear lack of cultural experiences in the present Japanese educational system.

In Japan, the guideline of MEXT says that one of the purposes of English Education is intercultural understanding. As is mentioned before, as regard to materials, teachers should take up a variety of suitable topics that lead to deepen the intercultural understanding. Activities of intercultural understanding education are performed in many subjects. The definition is not clear. Ikeno (2000, p.18) described the feature of the education as follows and has distinguished it from "International Understanding" education.

[1] Cultivation of world citizen consciousness.

[2] Cultivation of a tolerant attitude toward different cultures and the mind to respect those cultures

Furthermore, Ikeno (2000) states that the activity of intercultural education is classified into two types: knowledge approach and experience approach. He states that as an example of knowledge approach, the cultural understanding through linguistic analysis is a unique activity in the department of English education.

Next, in teaching of culture, Seelye (1985) suggests seven goals of cultural instruction as 
follows.

1. The sense, of functionality, of cultural conditioned behavior

2. Interaction of language and social variables

3. Conventional behavior in common situations

4. Cultural connotation of words and phrases

5. Evaluating statements about a society

6. Researching another culture

7. Attitudes toward other cultures

These elements are crucial in the global world, but we can hardly find the number 4 and 5 in the guideline of the MEXT in Japan. Textbooks need to be effective in completing these goals.

\subsection{Cultural Materials for Japanese EFL Learners}

Cortazzi and Jin (1999) gives three types of cultural information: target cultural materials, source cultural materials, and international target cultural materials. Those three points are very important for the English textbooks. Hence, the purposes of understanding other cultures, understanding self-culture, and global understanding are presented as a criterion in this study.

McKay (2000) suggested the implication for cultural materials in the classroom. She states what to include as content depends on the background and goals of the students and teacher. In EFL contexts like Japan, various cultural contents provide students with chances to learn more about their own culture and master English to explain culture to others. In the guideline, four special perspectives are given in the materials. They are materials that are useful in understanding various viewpoints and ways of thinking, deepening the understanding of the ways of life and cultures of Japan and foreign countries, deepening the international understanding, and deepening individual thinking on humanity, society, nature, etc.

In this paper based on these considerations, the materials are analyzed from the perspective of intercultural understanding. Fifteen of the high school textbooks are chosen to analyze from a viewpoint of cross-cultural understanding about the subject matters. Then the characteristics of the contents included in the textbooks will be made clear in this research.

\section{Significance of the Study}

The English textbooks are main sources for teaching cultural issues all over the world. It is clear that those materials can have some effects on students learning English. The importance of contents of the textbooks earns students a high priority in the EFL classroom. The present study attempts to gain more specific information for teaching cultural issues in the EFL environment. A better understanding of English textbooks used at Japanese high schools may assist EFL teachers and curriculum materials' designers to provide English teaching materials that suit English learners not only in Japan but also in other countries. 


\section{Macrothink \\ International Journal of English Language Education \\ ISSN 2325-0887 \\ 2016, Vol. 4, No. 2}

\section{Purpose of the Present Study}

Previous studies elucidated past materials of high school level English textbooks. Yet the cultural articles seen in present high school textbooks have not been made clear enough as far as I know. Therefore the present study aims to perform a qualitative analysis of cultural materials shown in the main passage of English textbooks used in the course of Communication English I .

The definition of intercultural education in this research is to give students information concerning various cultures of the world through English, make them aware of the varieties of cultures and respect not only the Japanese culture but also other cultures, and heighten students' awareness of being Japanese citizens living in a global community and cultivate a spirit of international cooperation. In this definition 'cultures' refer to the daily lives, manners and customs, stories, geographies, histories, traditional cultures, the culture of the young, the environment, human rights, and war of the people of the world and the Japanese people.

The research task of this paper is to show clearly what kind of subject matters are seen in fifteen of the present textbooks by investigating those textbooks based on a new course of study. The following points are viewpoints of analysis for the research task. Research questions are shown as followings.

1. What fields of contents are presented in the cultural materials?

2. What nations are informed in the materials?

3. What are the purposes of the materials treated in the present textbooks?

4. What is the rate of concrete culture and abstract culture in the cultural subject matters for intercultural understanding?

\section{Method and Procedure}

To achieve the goals of the study, the author chose the fifteen English textbooks used at Japanese high schools. Then those textbooks were analyzed in the following procedure by the author.

\section{(ア)Materials}

In Japanese high schools, the English course is divided into seven subjects: Basic Communication English, Communication English I, II, III, English expressions I, II, and English conversation. The objects applicable to analysis in this research are top fifteen in sale of the high school English textbooks that are approved by MEXT in the course of Communication English I . The class is worth three credits.

Table 1 shows the high school English textbooks targeted for the analysis in the present study.

They were selected from twenty-five Communication English textbooks. Analysis units are 'Lesson', 'Chapter', and reading materials such as 'Let's Read' and 'Reading.' Adopted numbers mean numbers of textbooks that were chosen in Japanese high schools. The rate unit is percent. 
Table 1. Order of adoption rate in English textbooks in 2014 (Cited from Naigaikyoiku p. 76)

\begin{tabular}{|c|c|c|c|c|}
\hline Ranking & Publisher & Name & $\begin{array}{l}\text { adopted } \\
\text { number }\end{array}$ & rate \\
\hline 1 & Tokyo shoseki & $\begin{array}{l}\text { All Aboard ! Communication } \\
\text { English I }\end{array}$ & 144136 & 11.3 \\
\hline 2 & Sanseido & VISTA English Communication I & 113617 & 8.9 \\
\hline 3 & Sanseido & $\begin{array}{l}\text { CROWN English Communication } \\
I\end{array}$ & 107115 & 8.4 \\
\hline 4 & Sanseido & MY WAY Communication $I$ & 76951 & 6 \\
\hline 5 & Suken shuppan & COMET English Communication I & 73840 & 5.8 \\
\hline 6 & $\begin{array}{l}\text { Daiichi } \\
\text { gakushusha }\end{array}$ & Vivid English Communication I & 71718 & 5.6 \\
\hline 7 & Keirinkan & $\begin{array}{l}\text { ELEMENT English Communication } \\
I\end{array}$ & 66603 & 5.2 \\
\hline 8 & Tokyo shoseki & $\begin{array}{l}\text { Power On Communication English } \\
I\end{array}$ & 65149 & 5.1 \\
\hline 9 & Keirinkan & Landmark English Communication I & 62330 & 4.9 \\
\hline 10 & Suken shuppan & $\begin{array}{l}\text { BIG DIPPER } \\
\text { Communication I }\end{array}$ & 56948 & 4.5 \\
\hline 11 & $\begin{array}{l}\text { Kirihara } \\
\text { shoten }\end{array}$ & $\begin{array}{ll}\text { PRO-VISION } & \text { English } \\
\text { Communication I } & \\
\end{array}$ & 48329 & 3.8 \\
\hline 12 & Bun-eido & Grove English Communication I & 44306 & 3.5 \\
\hline 13 & $\begin{array}{l}\text { Kyouiku } \\
\text { shuppan }\end{array}$ & $\begin{array}{l}\text { New ONE WORLD Communication } \\
I\end{array}$ & 40804 & 3.2 \\
\hline 14 & Tishuukann & Compass English Communication I & 36478 & 2.9 \\
\hline 15 & Tokyo shoseki & $\begin{array}{l}\text { PROMINENCE Communication } \\
\text { English I }\end{array}$ & 36019 & 2.8 \\
\hline
\end{tabular}

$1044343 \quad 81.9$

\section{(イ)Research Questions}

The first research question is what kind of contents are treated in the cultural materials? The contents of the cultural articles were classified into the following eleven categories in Table 2. The examples of each categories are shown in right side. These examples are basic classifications of the lessons in English textbooks.

Table 2. Cultural Categories and Content

\begin{tabular}{|c|l|}
\hline Categories & \multicolumn{1}{c|}{ Content } \\
\hline Manners and Customs & $\begin{array}{l}\text { seasonal events / general customs } \\
\text { the origins or meanings of events or behaviors } \\
\text { viewpoints and thinking patterns of one culture }\end{array}$ \\
\hline
\end{tabular}




\begin{tabular}{|c|l|}
\hline Daily Life & $\begin{array}{l}\text { food / clothes / family life } \\
\text { items related to daily affairs }\end{array}$ \\
\hline Geography \& History & $\begin{array}{l}\text { climate / sightseeing places / traffic / industry } \\
\text { historical explanation } \\
\text { past events / historic events of one country } \\
\text { products / energy / scientific development } \\
\text { information technology }\end{array}$ \\
\hline Natural Science & $\begin{array}{l}\text { handicapped people / racial discrimination } \\
\text { equality }\end{array}$ \\
\hline Human Right & novels /old legends \\
\hline Stories & $\begin{array}{l}\text { languages / non verbal communication / greeting } \\
\text { facial expressions }\end{array}$ \\
\hline language and communication \\
\hline School Life \\
between students \\
\hline environment & $\begin{array}{l}\text { protection of the earth / pollution } \\
\text { green energy }\end{array}$ \\
\hline youth culture & anime / comics \\
\hline war & Stories concerning war / Past events in war \\
\hline
\end{tabular}

The second research question is about the number and the rate of the areas treated in the textbooks. The countries shown in the cultural materials are classified into three regions based on the division suggested by Kachru $(1989,1990)$. Kachru $(1989,1990)$ suggested three areas concerning the use of English. In his division A is called Inner Circle, B is called Outer Circle, and $\mathrm{C}$ is called Expanding Circle. His division was adopted for the analysis of the second question. When one lesson treats two areas like A and B, it is counted as both points.

A The countries in which English is used as a native language (Inner Circle and e.g. the United States, Britain, Australia, etc.)

B The countries in which English is used as an official language (Outer Circle and e.g. Singapore, India, etc.)

$\mathrm{C}$ The countries in which English is used as a foreign language (Expanding Circle and e.g. Japan, South Korea, China, Thailand, etc.).

The third research question is about the purposes for intercultural understanding in the cultural materials. The following four purposes are used for the analysis: A understanding other cultures B self-culture understanding C global understanding, and D Comparison.

The fourth research question is about the rate of concrete culture and abstract culture in the cultural materials. The concept shown in Ashikaga, T., Fukita, R., \& Ikuta, Y. (2001) and Ikegami (2002) is used in this paper. The visible things such as building and festivals are 


\section{Macrothink}

International Journal of English Language Education

ISSN 2325-0887

2016, Vol. 4, No. 2

classified as concrete culture. The invisible things such as a sense of values, human relations, and personal views are classified as abstract culture. These factors are important because one purpose of cultural education is to foster students' humanity and glow up mentally.

\section{Results}

The following results were shown by the author. These results must give us some insights in cultural issues.

\subsection{Contents of the Materials for Intercultural Understanding}

Based on the information shown in Table 2, the materials in the lessons are categorized. Figure 1 shows the numbers of the twelve categories in fifteen textbooks.

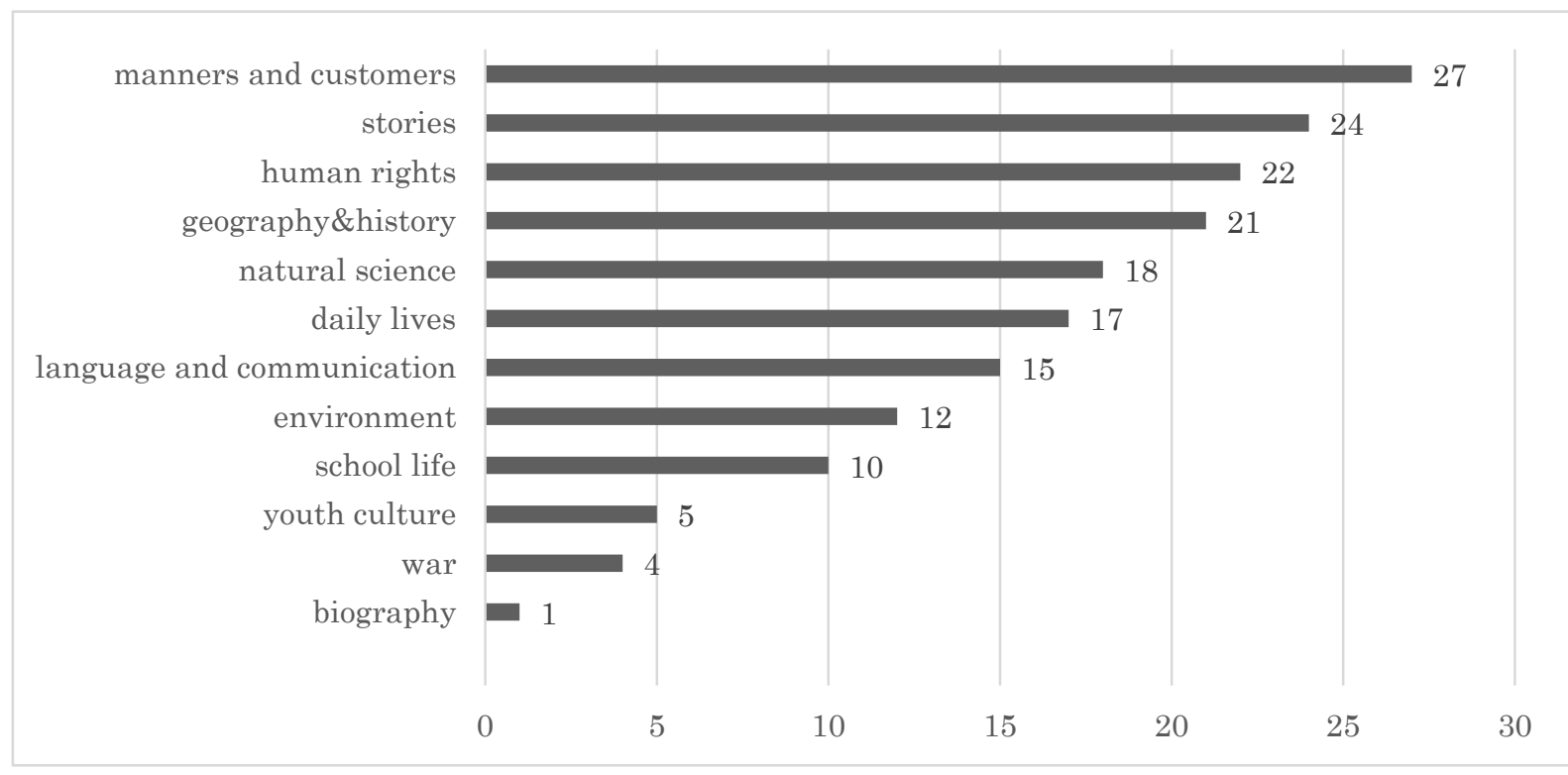

Figure 1. Categories of the cultural materials

As shown in Figure 1, there are many articles about manners and customs, and the categories of stories, human rights, and geography \& history follow the next. There are few subject matters about youth culture, war, and a biography. Although various categories are treated, it seems that many subjects are easy to handle. It seems that the number of natural science increased compared with the number of the English textbooks used at junior high school ( see Ookawa, 2013). Therefore, students will get a wide scope of information through the textbooks.

\subsection{Region and Nations of the Materials}

In order to understand tendencies found in the English textbooks in terms of nations of the world, the result has been tabulated according to the circle model proposed by Kachru. Figure 2 shows the number of three regions, Japan, and unknown materials in total. When the 
material includes some information concerning two areas, they are both counted.

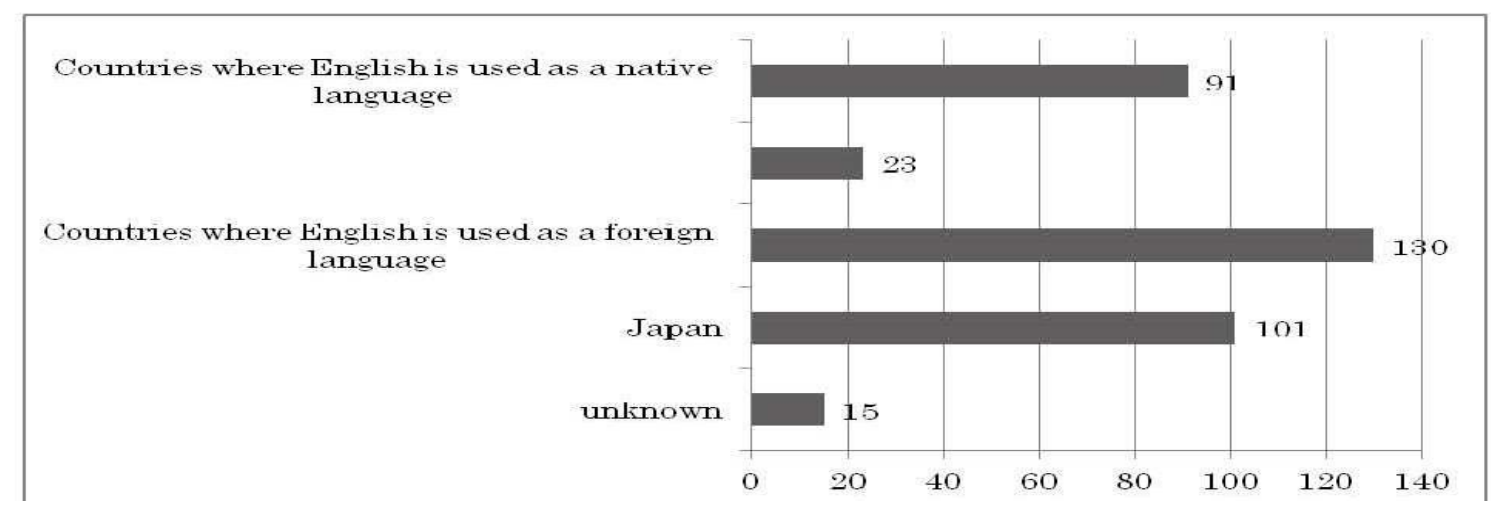

Figure 2. Areas treated in the cultural materials

As shown in Figure 2, the topics concerning countries where English is used as the first language are treated very frequently. Japan also occupies many of the lessons in total. On the other hand, the number of the lessons concerning countries where English is used as an official language is very small.

Table 3 presents the number and the percentage of the nations in which cultural topics are found in English textbooks in each circle. In Inner Circle, the U.S. appeared the most and the U.S. percentage stand at nearly $60 \%$ in total. The dominant emphasis on the U.S. can be understood clearly. In Outer Circle, Kenya and India are main targets, although the numbers are small. As can be seen, twelve countries are presented, but unfortunately, little information on these countries is available to students through the textbooks. It should be noted that many of these countries have been important trading partners for Japan. In Expanding Circle, there are so many nations included in the textbooks. However, much is focused on Japan. Japan stands at approximately $42 \%$ in the Expanding Circle. Asian countries such as China and Korea predominate, although the percentages are not large.

Table 3. Nations in which Cultural Aspects are Found

\begin{tabular}{|l|r|r|l|r|r|l|r|r|}
\hline $\begin{array}{l}\text { Inner } \\
\text { Circle }\end{array}$ & number & percent & $\begin{array}{l}\text { Outer } \\
\text { Circle }\end{array}$ & number & percent & $\begin{array}{l}\text { Expanding } \\
\text { Circle }\end{array}$ & number & percent \\
\hline the U.S. & 74 & 60.6 & Kenya & 6 & 24 & Japan & 101 & 41.9 \\
\hline U.K. & 20 & 16.4 & India & 5 & 20 & France & 16 & 6.6 \\
\hline Australia & 12 & 9.8 & Ghana & 3 & 12 & China & 14 & 5.8 \\
\hline Canada & 10 & 8.2 & $\begin{array}{l}\text { South } \\
\text { Africa }\end{array}$ & 3 & 12 & Korea & 12 & 5 \\
\hline Ireland & 4 & 3.3 & Malawi & 1 & 4 & Germany & 9 & 3.7 \\
\hline $\begin{array}{l}\text { New } \\
\text { Zealand }\end{array}$ & 2 & 1.6 & Nigeria & 1 & 4 & Holland & 9 & 3.7 \\
\hline
\end{tabular}




\begin{tabular}{|c|c|c|c|c|c|}
\hline Tanzania & 1 & 4 & Mexico & 5 & 2.1 \\
\hline Bangladesh & 1 & 4 & Turkey & 5 & 2.1 \\
\hline Singapore & 1 & 4 & Thailand & 5 & 2.1 \\
\hline Jamaica & 1 & 4 & Italy & 5 & 2.1 \\
\hline $\begin{array}{l}\text { Puerto } \\
\text { Rico }\end{array}$ & 1 & 4 & Russia & 4 & 1.7 \\
\hline \multirow[t]{28}{*}{ Total } & \multirow[t]{28}{*}{25} & & Spain & 4 & 1.7 \\
\hline & & & Greek & 4 & 1.7 \\
\hline & & & Brazil & 3 & 1.2 \\
\hline & & & Peru & 3 & 1.2 \\
\hline & & & Chile & 3 & 1.2 \\
\hline & & & Switzerland & 3 & 1.2 \\
\hline & & & Chile & 3 & 1.2 \\
\hline & & & Mongolia & 2 & 0.8 \\
\hline & & & Vietnam & 2 & 0.8 \\
\hline & & & Madagascar & 2 & 0.8 \\
\hline & & & Norway & 2 & 0.8 \\
\hline & & & Haiti & 2 & 0.8 \\
\hline & & & Iran & 2 & 0.8 \\
\hline & & & Bolivia & 2 & 0.8 \\
\hline & & & $\begin{array}{l}\text { United Arab } \\
\text { Emirates }\end{array}$ & 1 & 0.4 \\
\hline & & & Cambodia & 1 & 0.4 \\
\hline & & & Finland & 1 & 0.4 \\
\hline & & & Sweden & 1 & 0.4 \\
\hline & & & Venezuela & 1 & 0.4 \\
\hline & & & Argentina & 1 & 0.4 \\
\hline & & & Indonesia & 1 & 0.4 \\
\hline & & & Portugal & 1 & 0.4 \\
\hline & & & Iraq & 1 & 0.4 \\
\hline & & & Taiwan & 1 & 0.4 \\
\hline & & & Myanmar & 1 & 0.4 \\
\hline & & & $\begin{array}{l}\text { Bosnia and } \\
\text { Herzegovina }\end{array}$ & 1 & 0.4 \\
\hline & & & Poland & 1 & 0.4 \\
\hline & & & Total & 41 & \\
\hline
\end{tabular}

\subsection{Purposes of the Materials}

Figure 3 shows the number of the four categories of the purposes of the materials. When one lesson seems to have two purposes, they are both counted. 


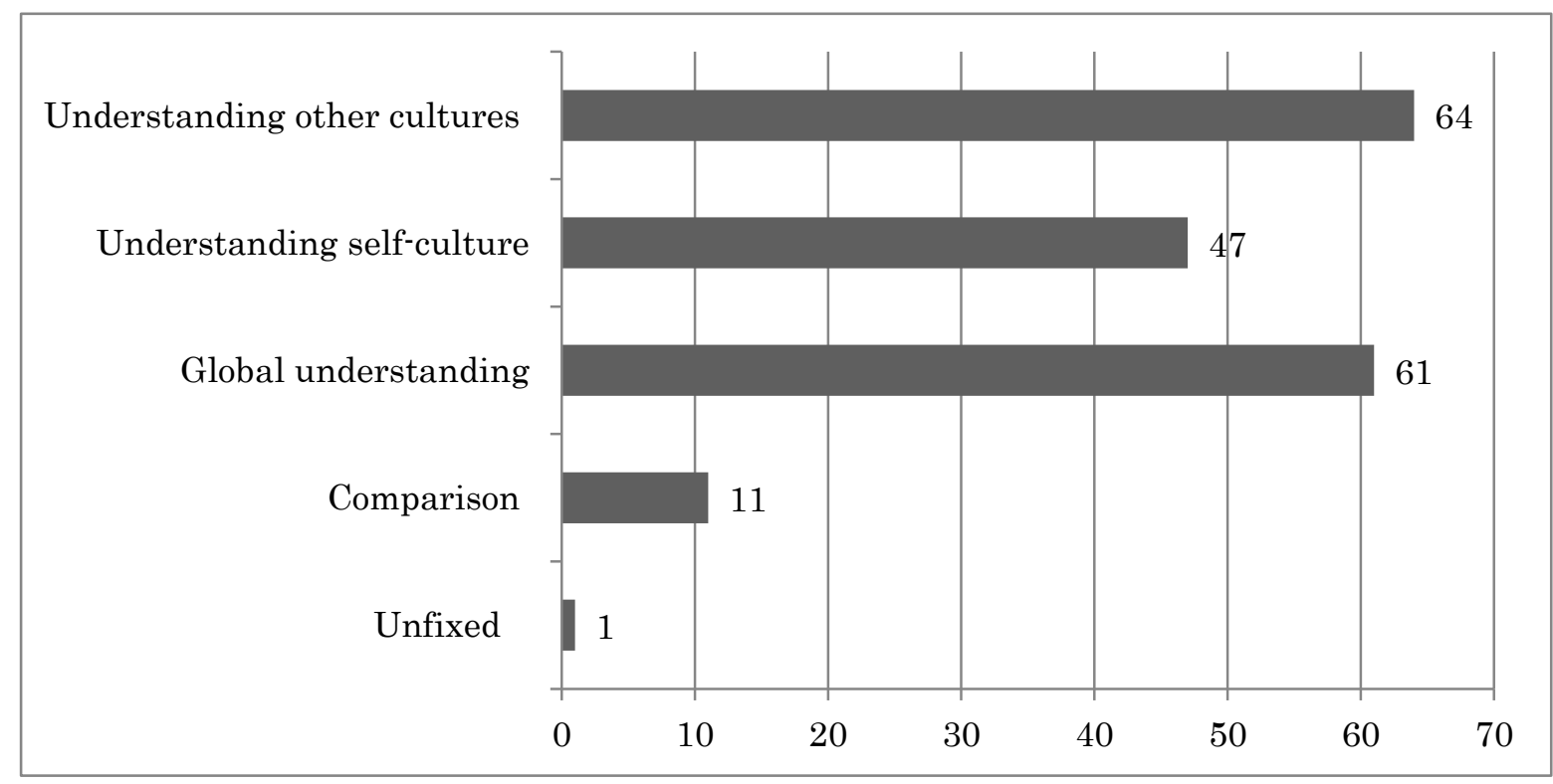

Figure 3. Purpose of the cultural materials

As shown in Figure 3, the number of understanding other cultures is bigger than other purposes. At the same time the numbers of understanding global understanding are large, while the number of comparison is so small. The materials for global understanding such as war, environment, and so on are frequently treated in the high school textbooks in order to heighten students' awareness of being Japanese citizens living in a global community.

\subsection{Comparison of Concrete Culture and Abstract Culture}

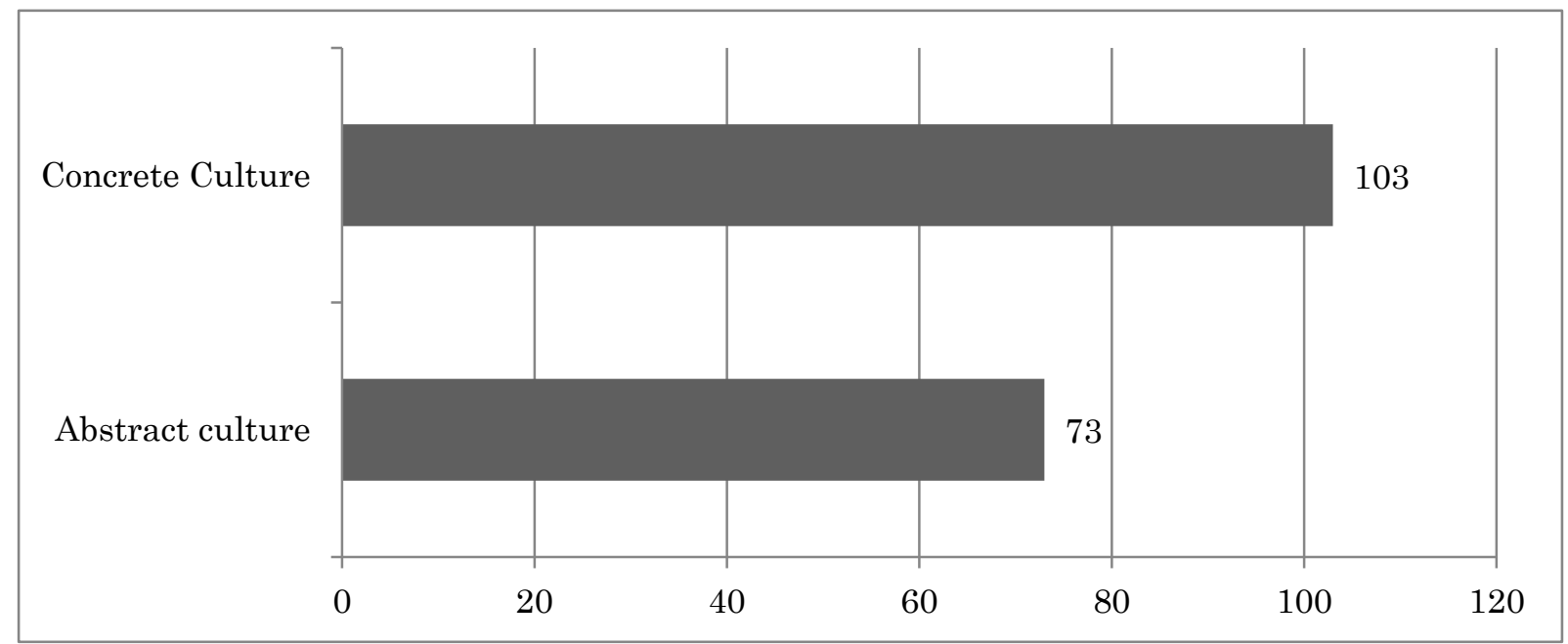

Figure 4. Comparison of Concrete Culture and Abstract Culture

Figure 4 shows the numbers of concrete culture and abstract culture included in the cultural materials for intercultural understanding in the high school textbooks. The number of the abstract culture is not bigger than that of concrete culture, but the materials of abstract culture are treated more frequently than junior high schools (see Ookawa, 2013). It is a good tendency that high school students have many chances to learn values that are different from 
their own and deepen the cultural issues.

\section{Discussion}

According to the data, the materials for intercultural understanding in the high school textbooks are summarized. First, all the lessons in the textbooks include some elements that are presented as concrete culture or abstract culture for intercultural understanding, and the categories of the contents are presented in various fields from the daily lives to customs and manners, history \& geography, traditional cultures, environment, war, and so on. This trend reflects the ministry's guideline clearly. Therefore, teachers have a great possibilities of teaching the cultural issues. They should explain the values or the personal ways of thinking behind the behaviors relating to themes in the textbooks or make students ask ALT teachers about the cultural articles because increasing humanity is also crucial in intercultural education.

Secondly, most of the regions in the materials for intercultural understanding are the countries where English is used as the first language and Japan. Too much is focused on America and Japan. However, the frequencies of the countries where English is used as an official language are very low, although some of them are trading partners for Japan. This should be changed because Japan has close relationship economically and politically. More information concerning these Outer Circle countries needs to be provided in the textbooks. One more point should be noted. It is natural that many topics of countries where English is used as a mother's language are shown in the textbooks because the contents of the articles are taught in the subject of English. However, English has been established as an international language, which means that students need to study materials of various countries for better intercultural understanding. It is preferable to increase the topics of countries belonging to Expanding Circle and make students get aware of the fact English is the international language. The reason is that English is used as a communication tool in a lot more countries where English is used as the foreign languages than countries where English is used as the first language. This point is discussed in Kachru (1989, 1990), Kamiya (2008) and Nakagawa (2011). They suggest English Education in terms of World Englishes and insist that English should be emphasized as the international language, not as American English. What is more, more countries such as Korea, China, and Taiwan that have close relationship with Japan should be presented as Yamanaka (2006) indicates, because the students who are Japanese will probably communicate with those people in the future.

Thirdly, the purpose of understanding other cultures is shown more than other purposes. This reflects the overall objective of deepening students' understanding of language and culture described in the minister's guideline. It will be interesting for high school learners to get a knowledge of foreign issues other than Japan, but teachers should not only give students a piece of information but suggest the materials in details and effectively.

Finally, it might be possible to create some ideas from the source culture and use the materials as supplementary information. Local materials will be preferred for deepening students' understanding of the Japanese culture. Some successes are reported in Yoshida (2006) and Ookawa (2012). Ookawa (2012) designed the locals material about Dogo Hot 
Spring which is a local historic place and made students deepen the understanding Japanese culture through the articles very successfully.

\section{Conclusion}

From the result of this research, it can be inferred that various kinds of topics suitable for high school students are presented in the English textbooks as a good balance of abstract culture and concrete culture in Japan. This characteristic can be said to be preferred because it follows the ministry's guideline. However, one point needs to be changed in Japanese high school level English textbooks. There are still biases because too much is focused on America and Japan. There is a marked lack of focus on nations in the Outer Circle and the Expanding Circle except Japan in comparison with the nations in the Inner Circle. According to the "white paper on tourism" from the government (2014), the number of travelers who visit Japan has been increasing recently, and the number of foreign travelers visiting Japan in 2014 is $13,410,000$ people. This has exceeded 2010 which had been the highest until then. The increase rate is nearly $29 \%$ compared with the previous year. According to the report, foreign travelers visiting Japan are dominated by China, South Korea and Taiwan. Canada and Australia indicate only several percent of the visiting foreigners. Therefore it would be beneficial for high school students to learn a variety of cultures concerning those countries because there is a great possibility that they will meet people from those countries in the future.

It is hoped that this research has been successful in offering some insights into the teaching of culture in English textbooks. In this research, some characteristics shown in the high school textbooks are made clear. It is crucial for teachers to recognize the tendency of the materials when engaged in the process of teaching of culture. It is hoped that this information will be useful for teachers when they are engaged in teaching English in their classroom.

However, as can be pointed in Yamanaka (2004) and Yamanaka (2006), there are no detailed instructions in the Ministry of, Culture, Sports, Science, and Technology about the region, the purpose, and so on. Although teachers are required to take up appropriate topics of various countries in the world, there is no specific information that is useful in choosing countries and categories. It can be confusing to decide the topics or make plans for cultural understanding because culture means a very wide meaning. It would be better if there were clear instructions on the teaching of cultures in these courses.

Finally, some limitations in this study should be noted. English textbooks are not the only way of teaching culture in classes. It is possible for students to learn the cultural issues in other ways. For instance, students can learn culture from ALT teachers or in other subjects such as general studies and social studies. However, it is true that the contents of the textbooks can have a great effect on the stage of cultural learning at high school. Therefore, a semiotic approach suggested by Weninger, C., \& Kiss, T. (2013) will be necessary for more reliable analysis of the cultural issues in English textbooks. They offer an alternative, semiotic framework that examines texts, images, and tasks and underscores two key insights: (1) that learners' meaning making in the classroom tends to be heavily guided and (2) that images and texts, even those with supposed cultural meaning of focus, seem to foster mainly 
linguistic competence. Further discussions are preferred for the better research of the cultural issues in English textbooks.

\section{References}

Alptekin, C. (1993). Target-language culture in EFL materials. ELT Journal Volume, 4712, 136-143. http://dx.doi.org/10.1093/elt/47.2.136

Ashikaga, T., Fukita, R., \& Ikuta, Y. (2001). A study of cultural aspects in Japanese EFL comunication. JACET, 33, 1-10.

Byram, M. (1990). Teaching culture and language: toward an integrated model.In. Dieter Buttjes and Michael Bryam (Ed.), Mediating Language and Cultures: Toward an Intercultural Theory of Foreign Language Education (pp.17-30). Clevedon: England

Chkravarti, P. (2008). Declonising and globalishin English studies: The case of English textbooks in West-Bengal, India. English in Education, 42(1), 37-52. http://dx.doi.org/10.1111/eie.2008.42.issue-1/issuetoc

Cortazzi, M., \& Jin, L. (1999). Cultural mirros: Materials and methods in the EFL classroom. In E. (Ed.), Culture in Second language teaching (pp. 196-219). Cambridge: Cambridge University Press.

Hino, N. (1988). Nationalism and English as an international language: the history of English textbooks in Japan. World Englishes, 7(3), 309-314. http://dx.doi.org/10.1111/j.1467-971X.1988.tb00240.x

Ikegami, M. (2002). One Approach to the Teaching Culture in English Education. ARELE, 13, 181-190.

Ikeno, O. (2000). Eigokyoiku ni okeru ibunnkarikai: kanousei to genkai [Intercultural Understanding in English Education: Possibilities and Limitations]. Ehime University Education Practical Center, 18, 17-30.

Kachru, B. B. (1989). Teaching World Englishes. Cross Current: An International Journal of Language Teaching and Cross-Cultural Communication, 16(1), 15-21.

Kachru, B. B. (1990). World Englishes and Applied Linguistics. World Englishes, 9, 3-20. http://dx.doi.org/10.1111/j.1467-971X.1990.tb00683.x

Kamiya, M. (2008). Nihonnjinwa dareno eigoo manabubekika- World Englishes toiu shiten karano eigokyouiku- [What English should the Japanese learn in terms of World Englishes] Sophia Junior College Journal, 28, 41-71.

McKay, L. S. (2000). Teaching English as an International Language: Implications for Cultural Materials in the Classroom. TESOL Journal, 7-11. http://dx.doi.org/10.1002/j.1949-3533.2000.tb00276.x

MEXT (Ministry of Education, Culture, Sports, Science and Techonlogy). (2010). Koutougattkou gakushu shidou youryou kaisetsu (Heisei22nen 5gatsu): Gaikokugo hen 
[Description of the course of study for high schools (May, 2010): Foreign language education]. Tokyo:Kairyudou.

Muroi, M. (1999). Global Issues in Senior High School English Textbooks - From the Viewpoint of Intercultural and Global Awareness - Chuubu English Language Society, 29, 171-178.

Muroi, M. (2004). 16nendo shiyou no koukoukyoukasho niokeru global issues - From the Viewpoint of Global Awareness -」[Global issues in high school textbooks in 2004]. Chuubu English Language Society, 34, 91-98.

Nakagawa, Y. (2011). Koukou eigo kyoukasho ni mirareru nihonjinno eigokanno ichikousatsu [A study of the Japanese view of English expressed in high-school English textbooks]. Asia English Research, 13, 39-62.

Ookawa, K. (2012). Bunkarikai wo fukammeru tameno kyozai kaihatsu to jissen [The design and practice for deepening students' understanding culture]. Chart Network, 68, 13-17.

Ookawa, K. (2013). Characteristics of the Cultural Materials Shown in Each Series of Junior High School English Textbooks. Shikoku English Language Society 33, 1-10.

Recoraro, D., Shaw, P., Malmstrőm, H., \& Irvine, A. (2011). English textbooks in Parallel-Lanugae Tertiary Education. TESOL Quarterly, 45(2), 313-331.http://dx.doi.org/10.5054/tq.2011.247709

Saitou, T. (2014). 2014 nendo koukou kyoukasho saitaku joukyou: Monkasho matome [The selection of the textbooks for Japanese upper secondary schools in 2014]. Naigai Kyoiku, p.83. Tokyo:Jijitsuushin sha.

Schneer, D. (2007). (Inter)nationalism and English Textbooks Endorsed by the Ministry of Education in Japan. TESOL Quarterly, 41(3), 600-607. http://dx.doi.org/10.1002/j.1545-7249.2007.tb00092.x

Seelye, H. N. (1985). Teaching Culture. Lincolnwood: NATIONAL TEXTBOOK COMPANY.

Shikano, T. (2001) Nihon no koukoueigo kyoukasho nioieru global na monndai (Global issues in high school English textbooks in Japan]. Globalkyouiku 4, 2-15.

Takeda, A., Eun-suk, Choi., Mochizuki, N. \& Watanabe, Y. (2006). Analysis and comparison of the junior and senior high school level English textbooks for Japan and Korea. Second Language Studies 25(1), 53-82.

Weninger, C., \& Kiss, T. (2013). Culture in English as a Foreign Language (EFL) Textbooks: A Semiotic Approach. TESOL Quarterly, 47(4), 694-716. http://dx.doi.org/10.1002/tesq.87

Yamada, Y. (2004). Chuugattkou no bunseki to hihan [Analysis and Criticism of junior high school English textbooks] Hiroshimashudo University, 45(1), 149-203.

Yamanaka, N. (2004). An evaluation of English textbooks from the viewpoint of culture 


\section{Macrothink}

based on the 2003 Ministry of education's course of study guidelines. JACET Journal, 39, 87-103.

Yamanaka, N. (2006). An evaluation of English textbooks in Japan from the viewpoint of nations in the inner, outer, and expanding circles. JALT Journal, 28(1), 57-76.

Yoshida, T. (2006). Chiiki eigo kyouzai "15 Stories of Saitama-ken” (Ver.2) no kaihatsu to katsuyou [Design and Use of the Local Materials "15 Stories of Saitama Prefecture" (Ver.2)] STEP BULLETIN, 18, 177-195.

\section{Copyright Disclaimer}

Copyright for this article is retained by the author(s), with first publication rights granted to the journal.

This is an open-access article distributed under the terms and conditions of the Creative Commons Attribution license (http://creativecommons.org/licenses/by/3.0/). 